INTERDISCIPLINARIA ARCHAEOLOGICA NATURAL SCIENCES IN ARCHAEOLOGY

\title{
Geophysical Investigations of the Bronze Age Andreevskoye Settlement in the Southern Trans-Urals (Russia)
}

\author{
Vladislav Noskevich $^{\mathrm{a}^{*}}$, Natalia Fedorova ${ }^{\mathrm{a}}$ \\ anstitute of Geophysics Ural Branch of the Russian Academy of Sciences, Amundsen Street 100, 620049 Yekaterinburg, Russia
}

\section{ARTICLE INFO}

\section{Article history:}

Received: $23^{\text {rd }}$ March 2020

Accepted: $19^{\text {th }}$ October 2020

DOI: http://dx.doi.org/10.24916/iansa.2020.2.1

Key words:

magnetic survey

ground penetrating radar

Bronze Age

archaeological site

South Urals

Russia

\section{Introduction}

At the end of the $20^{\text {th }}$ century, vast settlements attributed to the Bronze Age $\left(21^{\text {st }}-18^{\text {th }}\right.$ century BC) were discovered in Russia, in the steppe zone of the Southern Urals (Figure 1) (Gening et al., 1992). The earliest stage of the investigation was related to the decoding of aerial photos that allowed the specialists to discover and identify the majority of SintashtaArkaim - type settlements (Zdanovich and Batanina, 2007). The Sintashta settlements are typical by enclosed systems of fortification in contrast to other steppe Eurasian Bronze Age sites. The internal space has a very structured organization and it is almost entirely occupied by standard buildings that are organized into regular blocks. The total area of individual settlements ranges from 0.8 to 3.5 ha. The architecture of the settlements is almost completely destroyed; the earth walls of fortifications, ditches and housing depressions have been ploughed up. In modern times, the leading role played by geophysical research has directed investigations to the detection of the inner structure of sites.

Geophysical methods have been applied in archaeology for more than half a century. Resistivity methods and magnetometry have been applied in Europe since the 1950s (Atkinson, 1952; Aitken, 1974). Electromagnetic profiling and GPR surveying were introduced into archaeology in the 1980s-1990s (Dalan, 1991; Dabas et al., 2000). Significant advances in the study of various archaeological sites have been achieved using geophysical methods (Gaffney et al., 2002, Epov et al., 2016). Magnetic gradient surveys (Fassbinder, 2019), electrical resistivity tomography (ERT) (Tsokas et al., 2008) and ground penetrating radar (GPR) (Conyers, 2016) constitute the most informative geophysical methods for conducting archaeological research. In Siberia, the magnetic gradient method developed by German geophysicists has been successfully applied at the Chicha settlement (Late Bronze Age) which covers an area $400 \times 200 \mathrm{~m}$ (8 ha) (Becker and Fassbinder, 1999; Molodin et al., 2002).

Geophysical studies of several Sintashta fortified settlements (Arkaim, Kamennyi Ambar, Konoplynka, 


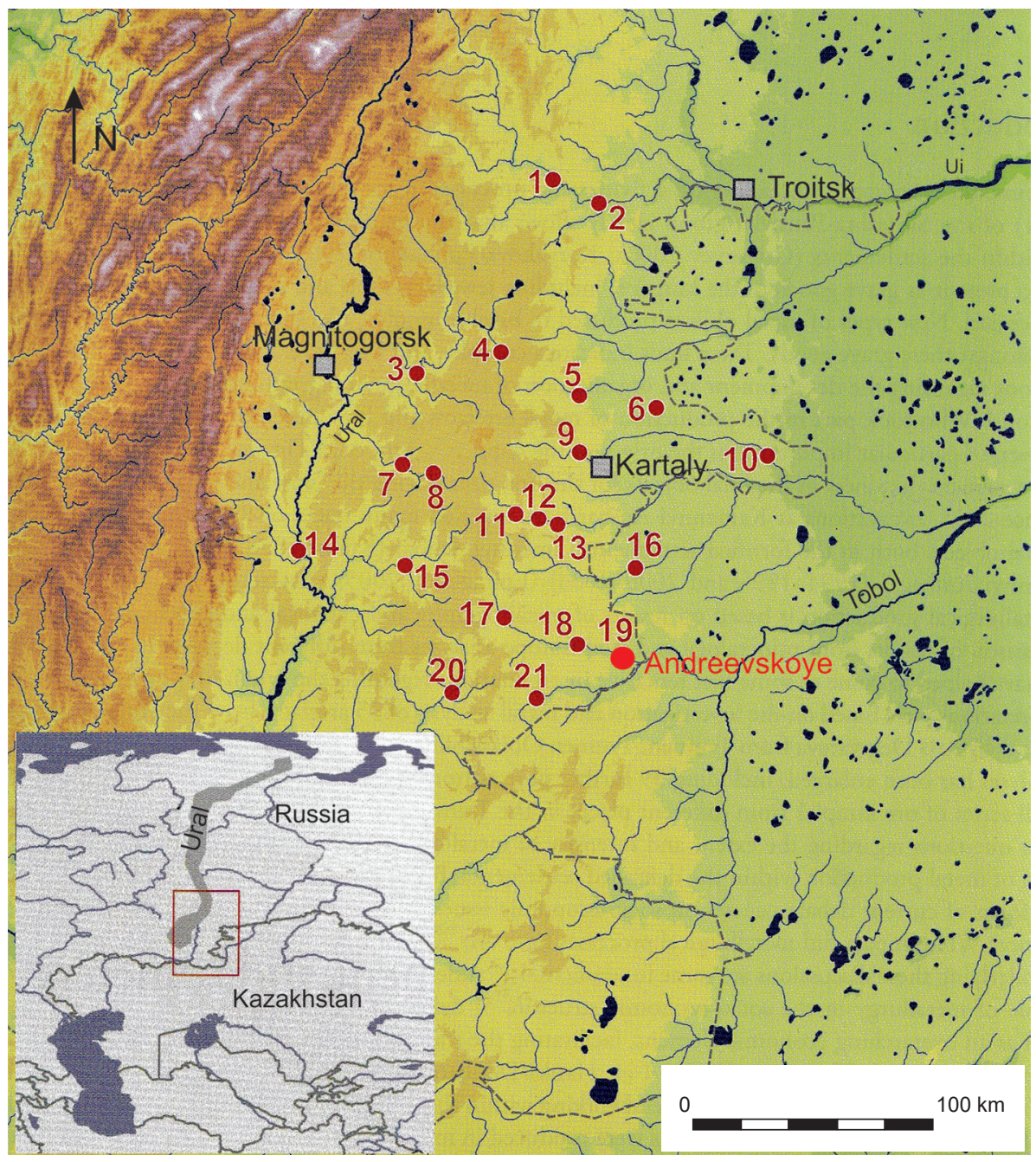

Figure 1. Trans-Ural with the fortified settlements of the Sintashta-Petrovka group (1-21) and the Andreevskoye settlement (19); after Zdanovich, Batanina, (2007). 1 - Stepnoye; 2 - Chernorechye II; 3 - Bakhta; 4 - Paris (Astafievskoe); 5 - Ustye; 6 - Chekatay; 7 - Kuisak; 8 - Sarym-Sakly; 9 - Rodniki; 10 - Isiney; 11 - Konoplanka; 12 - Zhurumbay; 13 - Kamennyi Ambar; 14 - Kizilskoe; 15 - Arkaim; 16 - Kamysty; 17 - Sintashta; 18 - Sintashta II; 19 - Andreevskoye; 20 - Alandskoye; 21 - Bersout.

Ustye, Sarym-Sakly, Ulak, etc.) have been carried out (Tibelius, 1995; Merrony et al., 2009; Noskevich et al., 2012; Patzelt, 2013; Hanks et al, 2013; Fedorova et al., 2014; Bakhshiev et al., 2018). Geomagnetic prospection has been effective in the investigation of fortifications and interiors due to a great variety of soils with magnetic properties higher than the surrounding ground. Magnetic anomalies reveal the exact position of outer defensive walls and ditches, the layout of buildings inside the settlements, and the existence of wells, household pits and ovens. The maps of magnetic anomalies indicate sites for further, moredetailed, study using archaeological and other geophysical methods, thus significantly reducing the risk of conducting blind excavations. GPR surveying allows the structure of fortifications to be determined, as well as the depth of ditches and wells to be inferred (Noskevich et al., 2012; Epimakhov et al., 2016).

As a part of the continuing geophysical research on the Sintashta-Arkaim settlements, this article presents our latest results regarding the Andreevskoye site. The micro-magnetic gradient survey covered the whole territory of the settlement $(200 \times 240 \mathrm{~m})$, while the GPR survey was conducted in several sections of the fortifications.

\section{Brief description of the Andreevskoye settlement}

The ruins of the Andreevskoye fortified settlement attributed to the Bronze Age are located on the left bank of the Sintashta River (7.7 km southeast of the Andreevsky village, Chelyabinsk region, Russia). The modern riverbed, together with the ancient one, form a peninsula (Figure $2 \mathrm{a}$ ).

The site is located on the very edge of the floodplain terrace, on the bank of the ancient riverbed of the Sintashta River. No full-scale archaeological excavations have been carried out at this site. Small exploration works had been carried out in two pits in the northern and southern parts of the settlement (Tairov et al., 1995). Fragments of ceramics presumably belonging to the Sintashta culture $\left(21^{\text {st }}-18^{\text {th }}\right.$ centuries BC) were found. In similar settlements (Kamennyi Ambar, Bersaut, etc.), radiocarbon analysis confirms these dates (Epimakhov, Krause, 2013). The total dating interval for Sintashta constitutes the period 2010-1770 BC. (Molodin et al., 2014).

The ruins of the defensive ditches and walls outline the borders of the site. The settlement has multiple layers and is characterised by a complex configuration, which is formed by three rectangular systems of defensive structures 
(Tairov et al., 1995). Drawing on aerial photographs and ground-based archaeological research, a plan of the settlement had been produced (Zdanovich and Batanina, 2007), featuring three settlements (A, B and C) that were heterogeneous in time (Figure 2b). The earliest is settlement A. Settlement B emerged in the southern part of settlement A after it ceased to be used. Settlement C, which appeared when settlement B was still in operation, reflects the late stage in the life of the settlement.

The photographs revealed that the ruins of defensive walls vary from 2.5 to 15 metres. Zdanovich and Batanina (2007) interpret the numerous gaps in them as entrances to the settlements. Their plan shows 9 entrances. There are housing depressions within the settlement, with their sizes ranging from $3 \times 5 \mathrm{~m}$ to $10 \times 23 \mathrm{~m}$.

According to the archaeological excavations, the inhabitants of the settlements like Sintashta - Arkaim were mainly engaged in cattle breeding (Koryakova et al., 2018). Preliminary results of isotope studies indicate that in the first half of the $2^{\text {nd }}$ millennium $\mathrm{BC}$, both people and animals (herds) did not leave the river valley for long distances, leading, in general, a sedentary lifestyle (Koryakova et al., 2019).

\section{Micro-magnetic survey}

The territory of the site constitutes an area of $200 \times 240 \mathrm{~m}$ (Figure 2), which was covered by the magnetic survey (at a scale of 1:50). For convenience in conducting the survey, this territory was divided into square sections $(40 \times 40 \mathrm{~m})$, with one of the sides being aligned with the magnetic meridian. The modulus of magnetic induction was measured in each square with $0.5 \mathrm{~m}$ station spacing and $0.5 \mathrm{~m}$ line spacing. In order to reduce the errors associated with the operator and data acquisition equipment, all measurements were performed in one direction - from south to north.
Measurements were made using gradient magnetometers (a Canadian SM-5 Navmag and a Russian MMPG-1), with their sensors being arranged vertically at heights of 0.3 and $2 \mathrm{~m}$ from the surface of the earth, respectively.

When performing measurements using MMPG-1, the lower sensor of the magnetometer was located exactly above the station. The survey error came to $\pm 1 \mathrm{nT}$. Measurements with the SM-5 Navmag gradient magnetometer were performed continuously, with the recording interval being set at 1 second; the coordinates of the measurement points were determined using a GPS receiver (Garmin 78, USA) with waypoint averaging method accuracy less than $\pm 3 \mathrm{~m}$. Studies have shown that continuous mode increases the measurement error to $\pm 3 \mathrm{nT}$, mainly due to inaccuracies in coordinate references. On the magnetic map, this is manifested in the slightly blurred features of anomalies. Given that the anomalies over the fortification reach 5-25 nT, we have been able to determine the position of the defensive walls, as well as other walls within the settlement.

\section{Magnetic map and the reconstruction of the settlement plan}

Drawing on the results of field measurements, a map of magnetic anomalies was produced, which constitutes the difference between the measured values of the modulus of magnetic induction at the heights of $0.3 \mathrm{~m}$ and $2 \mathrm{~m}$ (Figure $3 \mathrm{a}$ ). We performed calculations and generated derivative maps in different directions, which more clearly identify anomalies caused by fortifications and the inner walls dividing the space into housing sectors - dwellings. Using these data, the plan of the settlement was reconstructed (Figure $3 b$ ).

Linear magnetic anomalies reveal the position of defensive walls. Geophysical and archaeological studies carried out at the excavations of other Bronze-Age settlements such as Kamennyi Ambar and Konoplyanka (Noskevich et al., 2012;
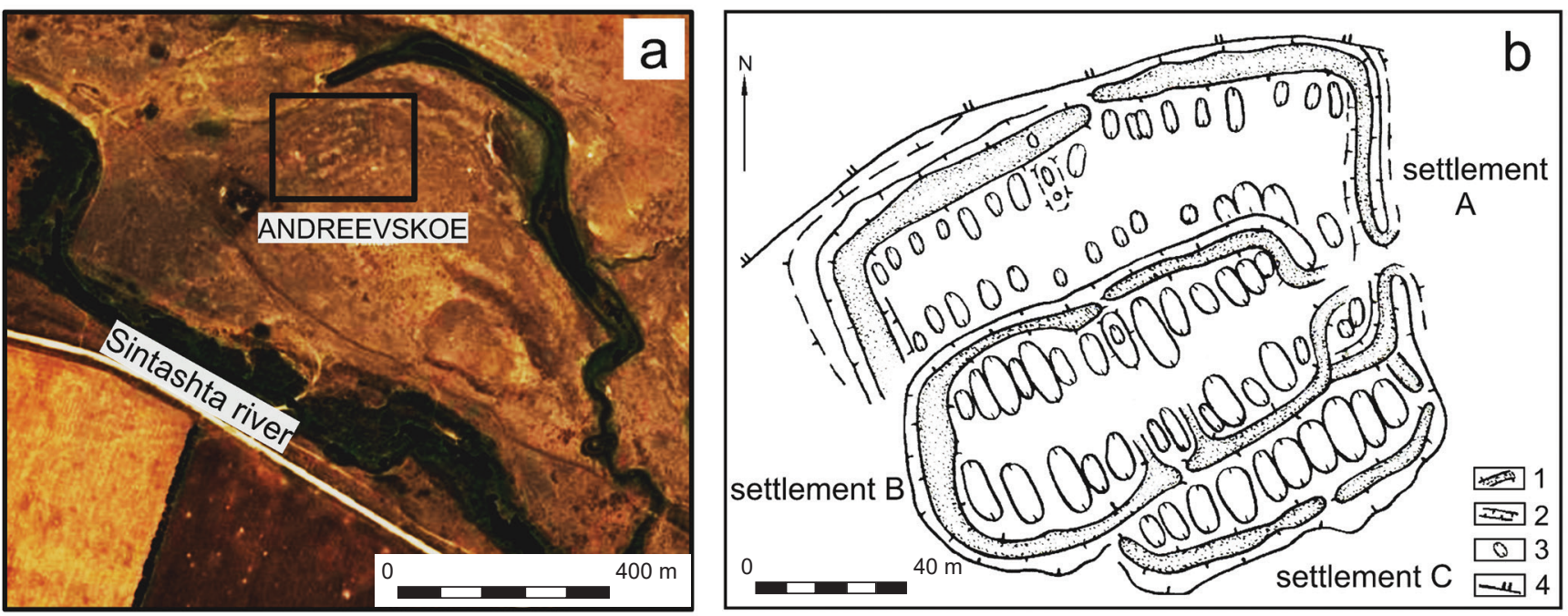

Figure 2. a: Present view of the Sintashta river valley (Andreevskoe settlement is inside the black rectangle); b: Plan of the settlement based on deciphering aerial photographs; after Zdanovich, Batanina, (2007). 1 - defensive walls; 2 - ditches; 3 - depressions from houses; 4 - floodplain terrace. 

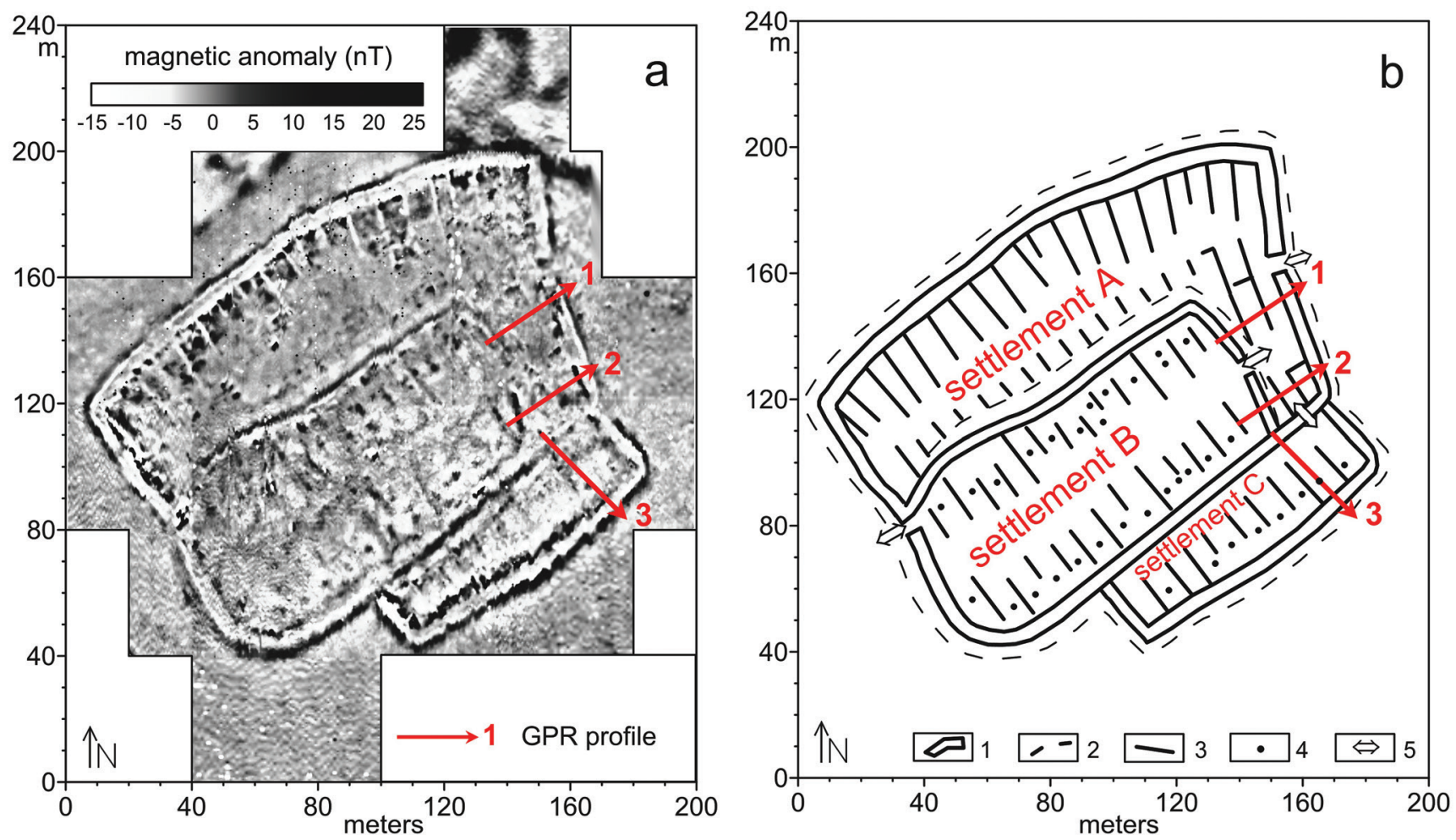

Figure 3. Andreevskoye settlement: a: Map of magnetic anomalies (straight lines show the position of the GPR profiles); b: Reconstructed settlement plan. 1 - fortification walls; 2 - boundary ditches; 3 - interior walls; 4 - well or household pit; 5 - entrances to the settlement.

Fedorova et al., 2014) indicate that the defensive walls are composed of earthen blocks and linear anomalies above the fortification are created by the layers of light-yellow loam (30-50 cm in thickness). The loam was used to strengthen the outer surface of the earth wall and the ditch up to its nearbottom part (Epimakhov et al., 2016).

Unlike the interpretations of photographs, geophysical studies reveal that the fortification walls of all three settlements had a thickness of 4-5 m. As previously noted, the thickness of walls in the plan-reconstructed drawing on the photographs (Figure $2 \mathrm{~b}$ ) varies from 2.5 to $15 \mathrm{~m}$, as during aerial photography only the ruins of walls were recorded. Magnetic anomalies help "see" deeper horizons and infer the size of the foundation for the walls.

The breaks in linear magnetic anomalies above the defensive walls indicate that the entrance to settlement A was located in the middle of the eastern wall, whereas another passage, which, evidently, was preserved during the functioning of settlement $\mathrm{B}$, was in the middle of the western wall. Another entrance to this settlement was in the middle of the eastern fortification. The entrance to the additional southern settlement $\mathrm{C}$ was situated in its north-eastern part. It appears that a section of the southern wall in settlement $A$ was destroyed, and the ditch there was filled in. The same conclusion follows from the results of the GPR survey given in the next section.

Therefore, the magnetic anomalies data do not confirm the presence of numerous passages in the defensive walls, discovered using aerial photographs and interpreted as entrances to the settlement. In addition, the magnetic survey does not confirm the complex structure of the defensive system at the entrances to settlements A and B, as well as in the southern part of the settlement where it separates villages B and C. Figure $2 \mathrm{~b}$ shows that thick walls extend beyond settlements and form corridors having a length of 8-25 $\mathrm{m}$.

The inner walls of villages manifest themselves differently in the magnetic field. The walls of settlement A, adjacent to the northern fortification wall, stand out quite clearly in the magnetic field. Negative magnetic anomalies having a width of 1.5-2 $\mathrm{m}$ are observed above them. Eighteen walls extend from the northern defensive wall, whose length can be confidently inferred on the basis of magnetic anomalies $(10-20 \mathrm{~m})$. Consequently, there were 19 buildings in this row. The width of housing sectors varies from 5 to 9 metres. The position of dwellings adjacent to the northern wall is consistent with the housing depressions discovered as a result of interpreting aerial photographs.

A lot of intense positive magnetic anomalies are observed inside a number of buildings in settlement $\mathrm{A}$, which are adjacent to the northern fortification. It can be assumed that there was a fire in this part, and as a result of oxidation, the magnetic minerals of soil and walls containing iron acquired high magnetisation. The accumulation of this material reveals the foundation pits of structures. The accumulation of this material makes it possible to clearly distinguish the foundations of dwellings.

The next row of dwellings in settlement $\mathrm{A}$ is manifested by low-contrast anomalies on the magnetic map, most of 
them having a length of 5-10 $\mathrm{m}$. Only in the eastern part the recorded anomaly a has length of $12-15 \mathrm{~m}$. All these anomalies were generated by the walls breaking off in the zone of an extended linear negative anomaly, which is caused by the ditch of the fortification of settlement B.

Along its entire length, the negative anomaly above the ditch has a fairly constant width of about 5-6 m. On our plan, the northern edge of this anomaly is indicated by a dashed line. Therefore, the walls in the second row of dwellings in settlement A were destroyed during the construction of the northern fortification wall and the ditch of settlement B.

In the south-eastern part of the settlement $\mathrm{A}$, there are several more dwellings from the third and fourth rows, whose long walls are parallel to the eastern defensive wall. The rest of the dwellings in these rows are attributed to the settlement B. Thus, the first settlement A consisted of four rows of dwellings, whose total number could have reached 65-70.

Then, presumably, the population of this settlement decreased by more than half and the northern part of settlement A was no longer used. Some of the houses (maybe 25 or 26) in the two southern rows of dwellings were fenced off with a new fortification, thus forming settlement B. Therefore, geophysical data confirm the conclusion drawn by Zdanovich and Batanina (2007) that settlement A is the earliest with settlement $B$ built later.

In settlement $\mathrm{B}$, it is not possible to outline the boundaries of dwellings as confidently as in the northern part of settlement A. In most cases, the walls of the houses are manifested only by low-intensity anomalies of a small length. Along the southern defensive wall, 12 isometric local anomalies can be clearly identified. These anomalies are observed almost in a straight line, with the distance between them being approximately the same (8-9 m).

Studies carried out at the excavations of other BronzeAge sites (Kamenny Ambar and Konoplyanka) revealed that similar local anomalies are noted over wells, household pits, and the remains of ovens (Multidisciplinary investigations, 2013; Fornasier et al., 2014). Local anomalies are also observed in the northern row of dwellings; however, they are not positioned as regularly as in the southern row. Thus, settlement B consisted of two rows of houses and their total number was reduced to 25 . The width and length of the dwellings came to 8-9 $\mathrm{m}$ and $15-20 \mathrm{~m}$, respectively.

Southern village $\mathrm{C}$ was divided into 10 sectors, whose sizes reached $9 \mathrm{~m}$ in width and $14-17 \mathrm{~m}$ in length. In some dwellings, anomalies from wells, or household pits, are observed. Linear magnetic anomalies are observed on both sides of the southern defensive wall in settlement C, with their intensity reaching $25 \mathrm{nT}$ and being significantly higher than over the defensive walls of settlements A and B. It appears that a different technology was used in the construction of the southern fortification; both sides of the wall were strengthened and a different material was used. Perhaps these were bricks or slabs of baked clay.

Thus, magnetic surveys provided new information on the structure of the fortifications and the position of dwellings within settlements during their operation, their number, as well as on numerous wells identified inside the houses. Drawing on these data, a plan of the settlement was produced which was more accurate than the one prepared on the basis of the results of interpreting aerial photographs.

\section{Ground-penetrating radar survey}

In order to study the fortifications, GPR surveys were carried out along the profiles (Figure 3a) intersecting the eastern and southern defensive walls of all three settlements. The survey was conducted using the SIR 3000 GPR system with 400 $\mathrm{MHz}$ and $270 \mathrm{MHz}$ antennae. The profiles were $34-42 \mathrm{~m}$ in length, with $0.1 \mathrm{~m}$ station spacing.

Obtained radargrams show the amplitudes of the reflected electromagnetic waves, with the positive part of the wave being marked black and the negative one being marked white. The raw data on the ordinate axis indicate the time of waves propagating from the antenna to the reflector and back to the receiver. Time-depth conversion requires the estimation of the velocity of electromagnetic waves, which depends on the physical properties of soils. To that end, measurements were performed along an additional $15 \mathrm{~m}$ profile with $0.1 \mathrm{~m}$ station spacing according to the common-depth-point method using two $100 \mathrm{MHz}$ antennae.

The velocity of electromagnetic waves was estimated according to the cross-correlation of traces in a gather using a module of the RADAN 7 software (GSSI, 2008). As a result, the velocity was estimated at $0.135 \mathrm{~m} / \mathrm{ns}$. The obtained value is consistent with the tabulated values of the velocity range $(0.122 \mathrm{~m} / \mathrm{ns}-0.150 \mathrm{~m} / \mathrm{ns})$ for dry loams making up soil in the study area (Finkelshteyn et al., 1986; Conyers, 2016). At a known value of wave velocity, the time-depth conversion was completed for these sections.

Figures 4-6 show the results of the GPR 3 surveys and its interpretation, with highlighting for the boundaries of reflections from fortifications and the interior of the settlements A, B, C interior. Profile 1 intersects the eastern fortifications of settlements $\mathrm{A}$ and $\mathrm{B}$, as well as partially the inner structures of settlement $\mathrm{A}$. The remains of these structures are noted in the interval $12-22 \mathrm{~m}$. In the interval of 0-12 $\mathrm{m}$, the fortifications of settlement B (wall and ditch), superimposed on the remains of the inner buildings of settlement A, are observed. The walls of the houses indicated by magnetic anomalies are clearly visible in the deep section. This indicates a later construction of the fortification in settlement $\mathrm{B}$ in the territory of the settlement $\mathrm{A}$. The most intense reflections are noted from the outer ditch in settlement A (interval 33-39), with the difference in depth reaching $0.5-0.7 \mathrm{~m}$.

Profile 2 also intersects the eastern fortifications of settlements A, B and the structures of settlement A. In addition, intense reflections from the wall separating the houses in settlement B are observed at the beginning of the profile. This profile is shorter than profile 1 (only $34 \mathrm{~m}$ in length); it ends above the wall of settlement A. 
Profile 1

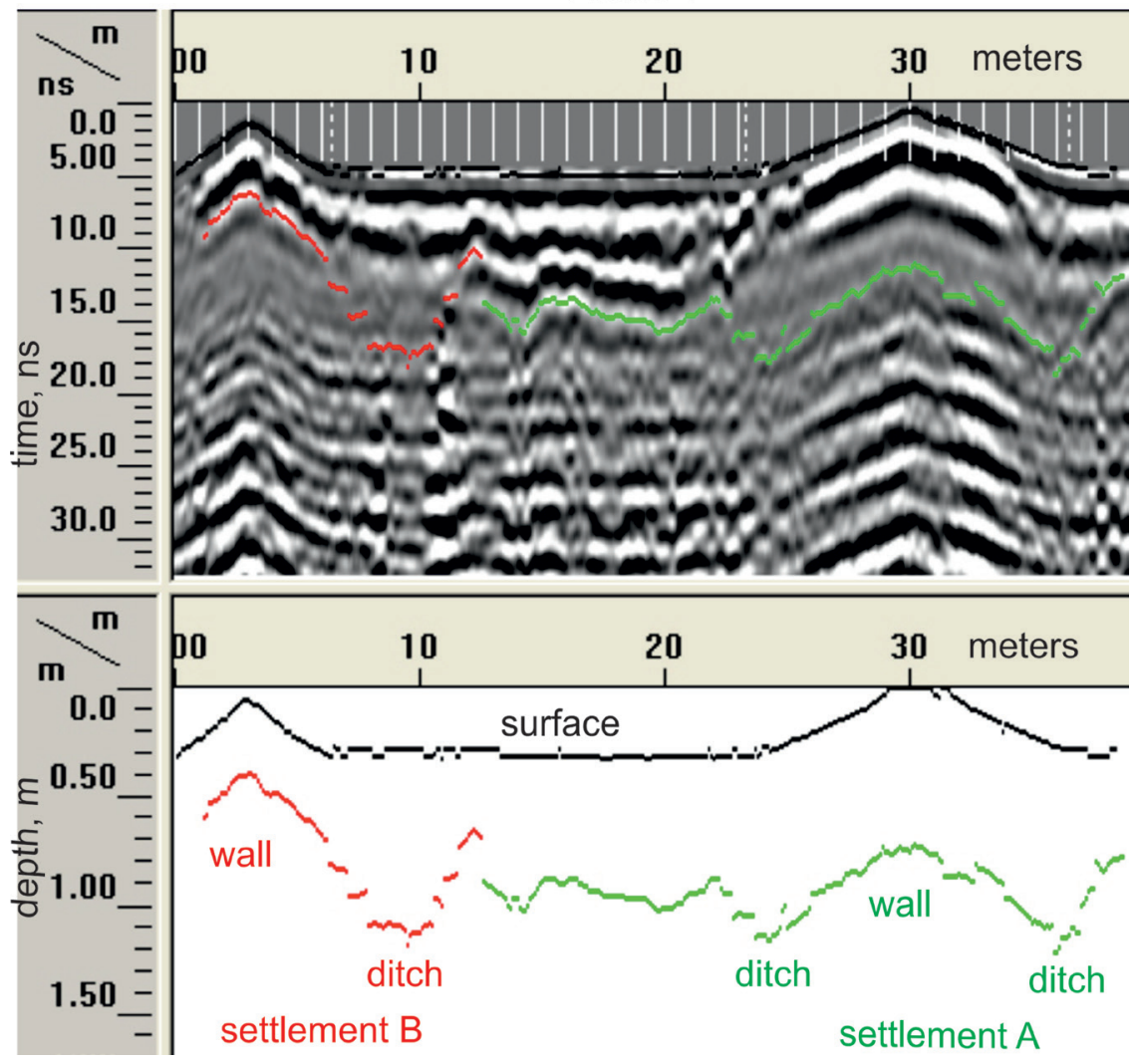

Profile 2

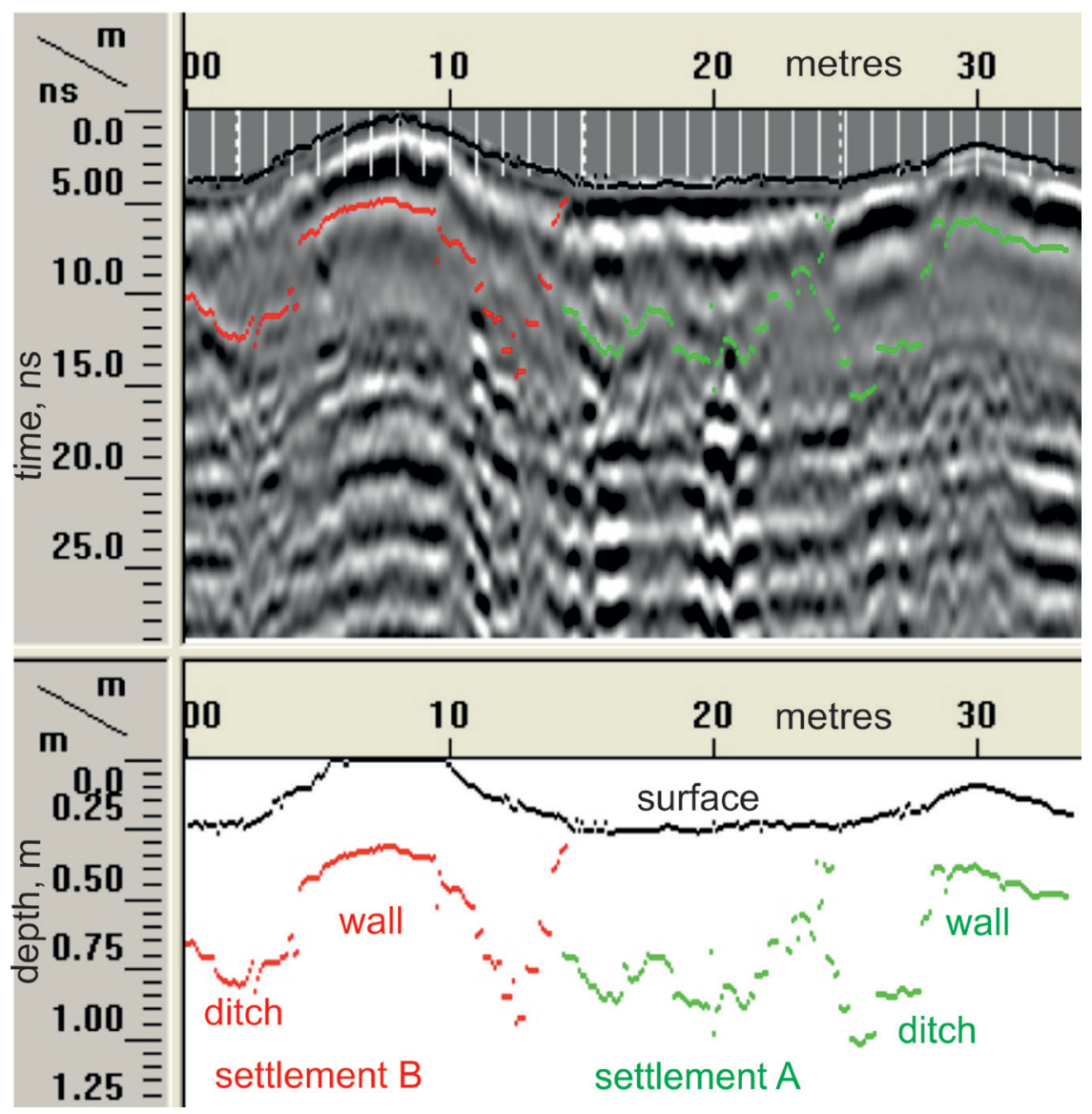

Figure 4. Results of the GPR (270 MHz) measurement processing and possible interpretation of the profile 1 .
Figure 5. Results of the GPR $(270 \mathrm{MHz})$ measurement processing and possible interpretation of the profile 2 . 
Figure 6. Results of the GPR $(270 \mathrm{MHz})$ measurement processing and possible interpretation of the profile 3 .

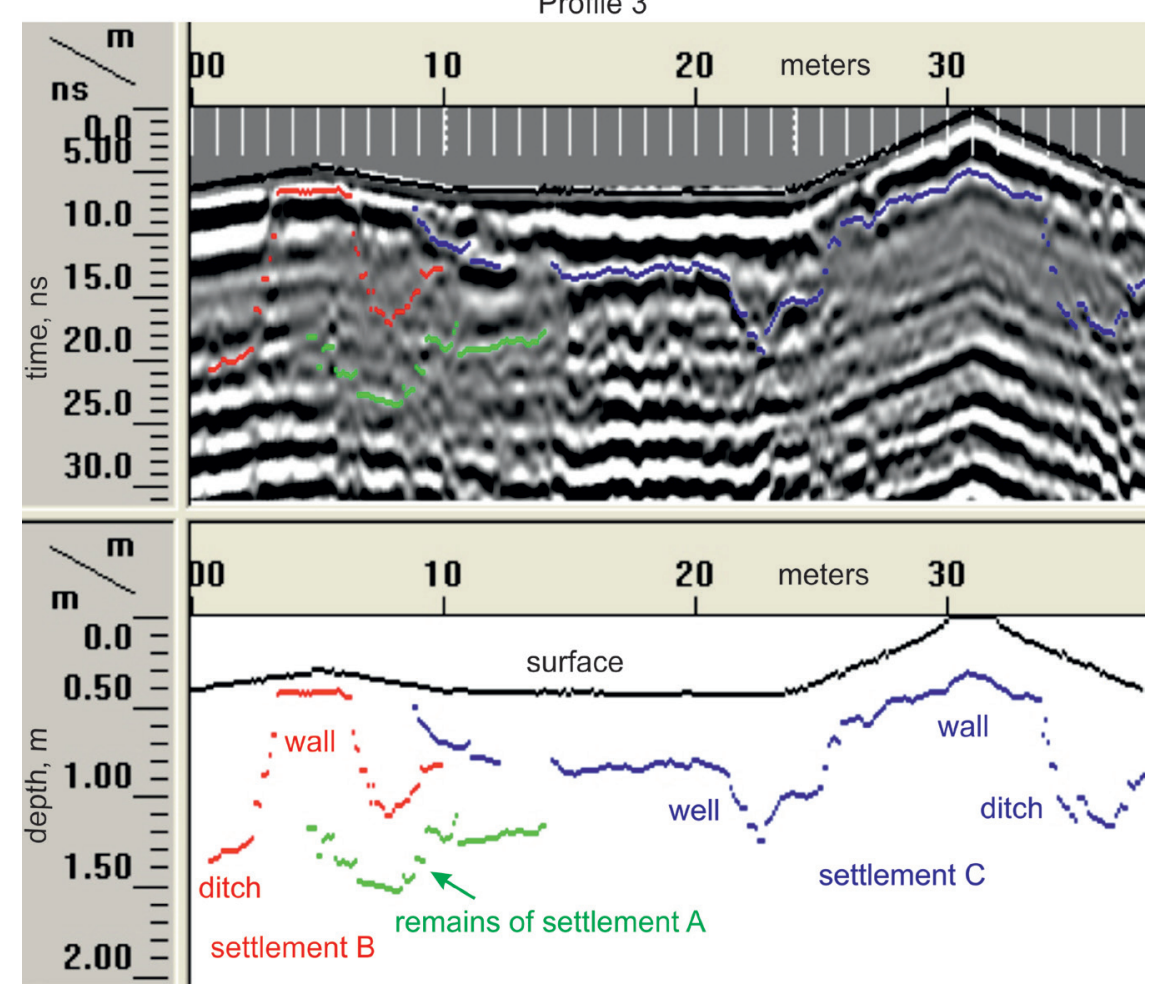

Profile 3 starts at the junction of the south-eastern wall in settlement $\mathrm{B}$ and the southern wall in village $\mathrm{A}$, then running across settlement $\mathrm{C}$ and its southern fortification. The section reveals that the remains of the southern wall in settlement $A$ are much more destroyed, with the surface elevation coming to $10 \mathrm{~cm}$, as compared to the outer defensive wall in settlement $\mathrm{C}$. The changes in the modern relief associated with this wall come to $30 \mathrm{~cm}$.

In addition, in the interval of 21-24 m, profile 3 intersects a local magnetic anomaly created by an ancient well or a utility pit. The section clearly shows reflections from the walls of a well at depths of $0.5-0.9 \mathrm{~m}$. Therefore, the floor of the structure is currently at a depth of $0.5 \mathrm{~m}$. The interval of 6-9 m reveals weak reflections from the edges of the ditch located on the outside of the wall in settlement A. Evidently, this ditch was filled up during the construction of settlement $\mathrm{C}$.

A comparison of the schematic plan of the settlement prepared on the basis of the magnetic survey with the results of the GPR survey allows us to conclude that the remains of the walls of houses, and even a well, indicated by magnetic anomalies are clearly visible in deep sections. Drawing on the interpretation, we can infer that the depth from the modern surface of the earth to the occupation layer in the dwellings of the ancient settlement comes to $50-70 \mathrm{~cm}$. The ditches surrounding the villages were shallow $(0.5-1 \mathrm{~m})$ and 2-4 $\mathrm{m}$ in width.

Zdanovich and Batanina (2007) concluded that settlement C was the most recent, based on the height of the ramparts above the fortifications. We also draw this conclusion from the measurements on the GPR profiles. Figures 4-6 show that the height of the ramparts above the defensive walls of the settlement A and B is $0.1-0.3 \mathrm{~m}$, and above the wall of the settlement $\mathrm{C}$ is much higher - circa $0.5 \mathrm{~m}$.

\section{Conclusion}

Geophysical studies have helped reconstruct a detailed plan of the Andreevskoye site, featuring three settlements A, B and $\mathrm{C}$, that were heterogeneous in time. Like other settlements of the Sintashta-Arkaim type, all three settlements (A, B and $\mathrm{C}$ ) were surrounded by closed fortification systems. The external defensive walls were about $4-5 \mathrm{~m}$ thick. The ditches surrounding the villages were shallow, $0.5-1 \mathrm{~m}$ and 2-4 $\mathrm{m}$ in width. The interior space had a very structured organization and was almost entirely occupied by standard buildings arranged in regular blocks. The width and length of the dwellings came to 8-9 $\mathrm{m}$ and $15-20 \mathrm{~m}$.

Our studies have confirmed the time sequence of the development phases of the settlement, established as a result of archaeological excavations (Tairov et al., 1995) and interpretation of aerial photographs (Zdanovich and Batanina, 2007). New details have been revealed about the layout of settlements, the location of wells, the size of houses and their number at different stages.

The earliest settlement A had a rectangular shape $(165 \times 100 \mathrm{~m})$ and consisted of four rows of dwellings divided by two streets. The total number of houses was approximately 65-70.

Then it appears the population of this settlement decreased by more than half and the northern part of settlement A was 
no longer used. Some of the houses in the two southern rows of dwellings were fenced off with a new fortification, in this way forming settlement B. Thus, settlement B had a rectangular shape $(115 \times 60 \mathrm{~m})$ and the total number of houses was reduced to $25-26$.

Southern settlement $\mathrm{C}$ which appeared when settlement B was still occupied, reflects the late stage in the life of the settlement. This annex was also rectangular in shape $(95 \times 25 \mathrm{~m})$, consisting of only one row of houses and was divided into 10 buildings.

Intensive local anomalies were found inside the dwellings of settlements B and C, which were created by wells and household pits.

We obtained GPR sections along three profiles, indicating the ditches and probably the dwellings of the ancient settlement under the sediments and ruins of walls. Based on our data, we can conclude that the depth from the modern surface to the occupation layer in the dwellings of the ancient settlement comes to $0.5-0.7 \mathrm{~m}$.

\section{Acknowledgments}

We express our appreciation and gratitude to the Corresponding Member of Russian Academy of Science P.S. Martyshko for his interest in geophysical research in archaeology. Thanks to his efforts, we have received modern geophysical instruments.

We are grateful to the anonymous reviewers who showed interest in our work and made helpful comments to improve our manuscript.

This work received financial support from the Institute of Geophysics Ural Branch Russian Academy of Science.

\section{References}

AITKEN, M.J., 1974. Physics and Archaeology. $2^{\text {nd }}$ ed., Oxford: Clarendon Press.

ATKINSON, R.J.C., 1952. Méthodes électriques de prospection en archeologie. In: A. Laming, ed. La découverte de passé. Paris: Picard, pp. 59-70.

CONYERS, L.B., 2016. Ground-penetrating Radar for Geoarchaeology. Analytical Methods in Earth and Environmental Science. New York: Wiley Publishing.

BAKHSHIEV, I.I., NOSKEVICH, V.V., NASRETDINOV, R.R., 2018. Geophysical and remote studies of the Ulak-1 fortified settlement of the Bronze age in Bashkir Trans-Urals: the correlation of the obtained data with the results of the archaeological excavations. Povolzhskaya Arkheologiya, 3 (25), 30-44.

BECKER, H., FASSBINDER, J.W.E., 1999. Magnetometry of a Scythian settlement near Chicha in the Baraba Steppe. In: Archaeological Prospection. Arbeitshefte des Bayerischen Landesamt für Denkmalpflege, 108. Munich, pp. 168-172.

DABAS, M., CAMERLYNCK, C., FREIXAS I CAMPS, P., 2000. Simultaneous use of electrostatic quadrupole and GPR in urban context: Investigation of the basement of the Cathedral of Girona (Catalunya, Spain). Geophysics, 65(2), 526-532.

DALAN, R.A., 1991. Defining archaeological features with electromagnetic surveys at the Cahokia Mounds State Historic Site. Geophysics, 56(8), $1280-1287$.

EPIMAKHOV, A.V., BERSENEVA, N.A., FEDOROVA, N.V.,
NOSKEVICH, V.V., 2016. Geophysics and archaeology of Bronze Age settlements - A Case Study from Kamennyi Ambar Fortified Settlement (South Urals). In: Proceedings 22 $2^{\text {nd }}$ European Meeting of Environmental and Engineering Geophysics. Near Surface Geoscience 2016. Barcelona, September 2016. Barcelona: European Association of Geoscientists and Engineers. DOI:10.3997/2214-4609.201602029

EPIMAKHOV, A.V., KRAUSE, R., 2013. Relative and absolute chronology of the settlement Kamennyi Ambar. In: R. Krause and L.N. Koryakova, eds. Multidisciplinary investigations of the Bronze Age settlements in the Southern Trans-Urals (Russia). Bonn: Dr. Rudolf Habelt Publishing, pp. 129-146.

EPOV, M.I., MANSHTEIN, A.K., BALKOV, E.V., DYADKOV, P.G., MATASOVA, G.G., BORTNIKOVA, S.B., KARIN, Y.G., KULESHOV, D.A., MOLODIN, V.I., KAZANSKY, A.Y., POZDNYAKOVA, O.A., 2016. Integrated archaeological and geophysical studies in West Siberia. Russian Geology and Geophysics, 57(3), 473-482.

FASSBINDER, J.W.E., 2019. Magnetometry in Archaeology - From theory to practice. Rossiyskaya arheologia, 3, 75-91. DOI:10.31857/ S086960630005672-8.

FEDOROVA, N.V., NOSKEVICH, V.V., IVANCHENKO, V.S., BEBNEV, A.S., MALIKOV, A.V., 2014. A magnetic survey of the bronze age archaeological settlements in the South Urals. Geophysical Research, 15(3), 24-37.

FINKELSHTEYN, M.I., KUTEV, V.A., ZOLOTAREV, V.P., 1986. The use of radar subsurface sounding in engineering geology. Moscow: Nedra Publishing.

FORNASIER, J., KRAUSE, R., KORJAKOVA, L.N., STOBBE, A., RUHL, L., SCHNEIDER, H., THIEMEEYER, H., PETERS, S., EPIMAKHOV, A.V., SHARAPOVA, S.V., PANTELEEVA, S.E., MOLCANOV, I.V., BERSENEVA, N.A., PATZELT, A., NOSKEVICH, V.V., 2014. Architektur, Wirtschaft und Landschaft der Bronzezeitlichen Siedlungen am Nordrand der Eurasischen Steppe im Trans-Ural (Russische Föderation). Eurasia Antiqua, 20, 229-272.

HANKS, B.K., CHECHUSHKOV, I.V., DUNAN, R.K., PITMAN, D., MUZHICH, B., MEDARICH, I., MORI, M., 2013. Recent results and prospects of research of the ancient Ustye settlement area and the lower Toguzak river valley. In: N.B. Vinogradov and A.V. Epimakhov, eds. Ancient Ustye: A fortified Bronze Age settlement in the South TransUrals. Chelyabinsk: Abris, pp. 393-416.

GAFFNEY, C., GATER, J., OVENDEN, S., 2002. The Use of Geophysical Techniques in Archaeological Evaluations. In: A. Taylor, ed. Institute of Field Archaeologists, 6, p. 22.

GENING, V.F., ZDANOVICH, G.B., GENING, V.V., 1992. Sintashta: Archaeological sites of the Aryan tribes of the Urals-Kazakhstan steppes. Chelyabinsk: South Urals Publishing.

GSSI, 2008. SIR-3000, RADAN, http://www.geophysical.com/software. htm, Geophysical Survey Systems, Inc. Salem, NH, USA.

KORYAKOVA, L.N., KRAUSE, R., SHARAPOVA, S.V., FEDOROVA, N.V., KOSINTSEV, P.A., ZAYKOV V.V., ANKUSHEV, M.N., 2018. Enclosed settlements of the Karagaily-Ayat river basin through the prism of the multidisciplinary approach. History of Science and Engineering, $1,22-36$.

KORYAKOVA, L.N., KRAUSE, R., SHARAPOVA, S.V., PANTELEEVA, S.E., KOSINTSEV, P.A., 2019. Archaeology of the lifestyle (investigating the Bronze Age sites of the Southern Trans-Urals). Ural Historical Journal, 4(65), 40-51.

MERRONY, C., HANKS, B., DOONAN, R., 2009. Seeking the Process: The Application of Geophysical Survey on some Early Mining and Metalworking Sites. Studies in honour of Barbara S. Ottaway. In: Universitatsforschungen zur prahistorischen Archaologie. Bonn: Metalsand Societies, pp. 421-430.

MOLODIN, V.I., PARZINGER, H., SCHNEEWEIB, J., GARKUŠA, J.N., GRIŠIN, A.E., NOVIKOVA, O.I., EFREMOVA, N.S., MARČENKO, Z.V., ČEMJAKINA, M.A., MYLNIKOVA, L.N., BECKER, H., FABBINDER, J., 2002. Čiča - eine befestigte Ansiedlung der Übergangsperiode von der Spätbronze zur Früheisenzeit in der Barabinsker Waldsteppe. Vorbericht der Kampagnen 1999-2001. Eurasia Antiqua, 8, 185-236.

NOSKEVICH, V.V., FEDOROVA, N.V., SOBOLEV, O.L., 2012. Reconstruction of archaeological fortified settlements of Southern Ural Mountains, of the Bronze Age on the magnetic data. In: Proceedings 
$18^{\text {th }}$ European Meeting of Environmental and Engineering Geophysics Near Surface Geoscience 2012. Paris September 2012. Paris: European Association of Geoscientists and Engineers. DOI: 10.3997/22144609.20143445

PATZELT, A.E., 2013. Geomagnetic investigation on Bronze Age settlements at Varshavka, Chelyabinsk Region In: R. Krause and L.N. Koryakova, eds. Multidisciplinary investigations of the Bronze Age settlements in the Southern Trans-Urals (Russia). Bonn: Dr. Rudolf Habelt Publishing, pp. 53-66.

TAIROV, A.D., BATANINA, I.M., KUZNETSOVA, O.A., 1995. Studies of monuments of the country of cities in 1994. Archive of the reserve "Arkaim". Chelyabinsk.
TIBELIUS, V.Y., 1995. Results of geophysical research on Arkaim. In: Russia and the East: Problems of interaction. Chelyabinsk: CSU, pp. 184-193.

TSOKAS, G.N., TSOURLOS, P.I., VARGEMEZIS, G., NOVACK, M., 2008. Non-destructive electrical resistivity tomography for indoor investigation: The case of Kapnikarea Church in Athens. Archaeological prospection, 15(1), 24-37.

ZDANOVICH, G.B., BATANINA, I.M., 2007. Arkaim - country of cities. Space and images. Chelyabinsk: Krokus Publishing. 
